\title{
The Cypriot Kingdoms between Athens and Persia: Cyprus IN THE CONFLicts OF THE 5TH CENTURY BC (497-411 BC $)^{1}$
}

\author{
Christian Körner \\ Universität Bern
}

\section{DEDICATED TO ANDREAS MEHL, IN GRATEFUL RECOGNITION FOR HIS FUNDAMENTAL CONTRIBUTION TO THE STUDY OF CYPRIOT HISTORY}

\begin{abstract}
Until the middle of the 5th century BC, Athens and Persia were struggling for supremacy in the Eastern Mediterranean. Due to its strategic importance, the island of Cyprus was affected by this conflict. Several Athenian interventions in Cyprus can be reconstructed from the written sources. Parallel to this larger conflict, wars between Cypriot kingdoms seem to have been an essential feature of the island's fragmented political landscape. Apparently, both forms of conflict - inner-Cypriot wars and interventions from the outside - affected each other.

In the following paper, I will analyse the interventions and conflicts in Cyprus in the 5th century BC and assess the role played by the Cypriot kings. In terms of method, I will approach these questions by analysing the written sources that provide information concerning political conflicts on the island during the 5th century BC. I will take a Cypriot perspective in order to show how inner-Cypriot rivalries intersected with the relationship to the major powers in the region. The overall impression is that between the unsuccessful Cypriot Revolt in $498 \mathrm{BC}$ and the accession to the throne of the most powerful ruler of the island, Evagoras I of Salamis (before $411 \mathrm{BC}$ ), the local kingdoms were rather the objects of Athenian and Persian interests than active players in the larger conflicts.
\end{abstract}

Keywords: Cyprus, Athens, Persia, Cypriot kings.

Of Erechtheis, these died in the war, in Cyprus, in Egypt, in Phoenicia, in Halieis, in Aigina, at Megara in the same year. ${ }^{2}$

1 I would like to thank Steve Gregoris and Anna Mettauer-Grothues for their valuable help with the English language.

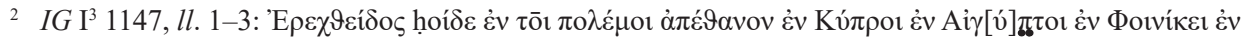

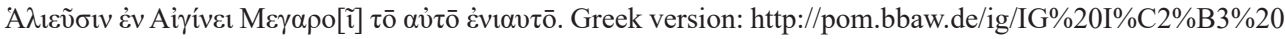
1147 (accessed: 24 January 2020); translated by S. Lambert and R. Osborne, https://www.atticinscriptions. com/inscription/IGI3/1147 (accessed: 27 December 2019). 
And the Athenian people, taking a tenth part of the booty, dedicated it to the god, and the inscription which they wrote upon the dedication they made ran as follows:

"E'en from the day when the sea divided Europe from Asia,

And the impetuous god, Ares, the cities of men

Took for his own, no deed such as this among earth-dwelling mortals

Ever was wrought at one time both upon land and at sea.

These men indeed upon Cyprus sent many a Mede to destruction,

Capturing out on the sea warships a hundred in sum

Filled with Phoenician men; and deeply all Asia grieved o'er them,

Smitten thus with both hands, vanquished by war's mighty power."3

When Medes and Kitians besieged the city Idalion in the year of Philokypros, (the son) of Onasagoras, king Stasikypros and the city - the Idalians - ordered that the doctor Onasilos, (the son of) Onasikypros and his brothers should treat the men wounded in battle without payment. ${ }^{4}$

All three texts refer to crucial events in the history of Cyprus during the 5th century $\mathrm{BC}$. The first is the introduction to an inscription listing the names of the soldiers who belonged to the Athenian phyle Erechtheis and fell in the year 460/459 BC; the first battleground mentioned is Cyprus. The second text is an epigram inscribed on an Athenian

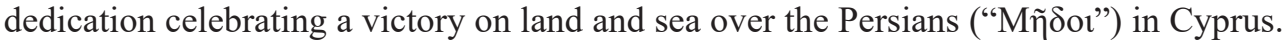
The third is a Greek inscription from Cyprus, written in the local Cypriot syllabary script and found in the city of Idalion; it is the introduction to the famous Bronze Tablet referring to a joint attack launched by Persians ("Medes") and the kingdom of Kition on the island's southern coast against the inland city of Idalion.

All these texts mention 5th century military conflicts involving Cyprus. And they all reveal the wider implications of these events: Cyprus came into focus when it impacted Athenian and Persian interests. But what exactly are the backgrounds of these conflicts? What were the Athenian and Persian interests on the island? And what was the role played by the Cypriot kings in these conflicts?

Trying to find answers to these questions is a difficult task: Cyprus' history in the years after the Cypriot Revolt (498 BC) and before the accession to the throne of the most important ruler of one of the island's kingdoms, Evagoras I of Salamis (before $411 \mathrm{BC}$ ), is shrouded in mystery, due to a lack of sources. This problem results from the fact that the surviving literary sources (Greek as well as the later Roman ones) all assume a mainland Greek, mostly Athenian perspective. Apparently, 5th century Cypriot affairs

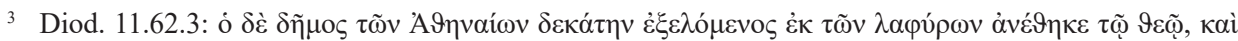

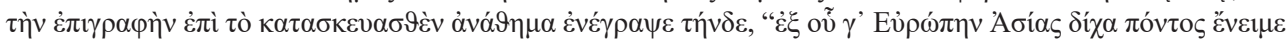

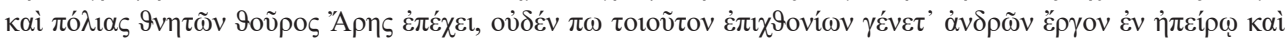

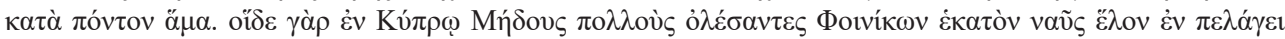

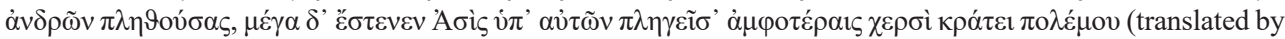
C. H. Oldfather). The epigram is attributed to Simonides: see Barns 1953, 167; Will, in: Diodoros 1998, 318.

${ }^{4} I C S$, no. 217 = Egetmeyer 1993, 56-58 = Egetmeyer 2010, 629-635, no. $1=$ Georgiadou 2010,

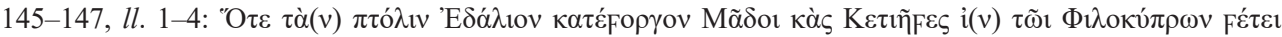

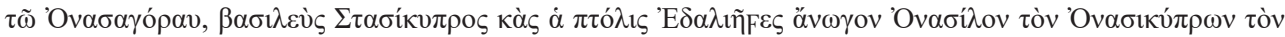

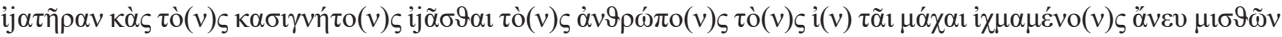
(Greek transcription: Georgiadou 2010, 146; translated by C. Körner). The Greek inscriptions from Cyprus are now being edited as volume XV of the Inscriptiones Graecae. At the time of writing this manuscript, the inscriptions of Idalion were still not published in $I G \mathrm{XV}$. 
were of little interest to ancient historiographers; only with the rise of Evagoras I did Cyprus once again become an occasional focus of Athenian attention.

Of course, coins as well as inscriptions originating directly from Cyprus provide us with the names of some of the Cypriot kings. But it is practically impossible to reconstruct historical events from these sources. The exceptional case of the Bronze Tablet of Idalion, the longest Cypriot inscription written in the local syllabary, only serves to prove this point: even though a siege of the city of Idalion by the Kitians and the Persians is mentioned, it is not possible to date this crucial event in the history of the city with any accuracy. We can only say with some certainty that the siege must have taken place in the 5 th century BC.

The few literary texts relating to Cypriot history in the years 498 to $411 \mathrm{BC}$ offer mere highlights, and we can only catch glimpses of what happened. Nevertheless, these years must have been of utmost importance for Cyprus since the two major forces in the Eastern Mediterranean, Athens and Persia, were fighting for influence in the region. In the following paper, I would therefore like to try and reconstruct at least some of the developments of the Cypriot kingdoms with regard to Athens and Persia in the 5th century. The time frame is furnished by two major events in the island's history, the Cypriot Revolt against Persia (498 BC) and the accession to power of Evagoras I of Salamis (before $411 \mathrm{BC}^{5}$ ). Both events show the Cypriot kings, especially those of Salamis, as active protagonists in the politics of the Eastern Mediterranean: Onesilus of Salamis, leader of the revolt of $498 \mathrm{BC}$, established contacts with Ionia and was able to win the support from the Ionians; Evagoras I of Salamis began to play an important role in the Eastern Mediterranean alongside the Persian kings, their satraps in Asia Minor, the Egyptian pharaohs and Athens. The contrast to the little information we have about the politics of the Cypriot kings in the years between 498 and $411 \mathrm{BC}$ could not be greater.

My methodical focus will be on the written sources that provide information concerning political conflicts on the island during these years. ${ }^{6}$ As I have already mentioned, most of these texts (with the exception of the Bronze Tablet) have an Athenian focus. Instead of reconstructing Athenian and Persian politics, I will try to take a Cypriot perspective and focus on the following questions:

1. Which incidents, conflicts and interventions concerning Cyprus in the years $498 \mathrm{BC}$ to $411 \mathrm{BC}$ can be reconstructed from the written sources?

2. What role did Cyprus play in the conflicts in the Eastern Mediterranean in the 5 th century BC?

3. To what extent were the Cypriot kings able to take initiative in these conflicts?

To start, it is of crucial importance to understand the relationship between the Cypriot kings and the Persian Great Kings. Therefore, I will first examine the situation of Cyprus

5 The beginning of Evagoras' reign cannot be dated with absolute certainty. $411 \mathrm{BC}$ is the terminus ante quem; for the question, see Körner 2017, 234-239.

6 Since it is not the aim of this paper to reconstruct dynasty-lists of the Cypriot cities, I will not refer to the numismatic evidence which provides the names of some of their kings. Neither will I focus on the archaeological material, since it is nearly impossible to establish immediate links between archaeology and the historical events referred to in the written sources of the 5th century BC. For a thorough analysis of the archaeological material and the cultural and economic relations between Cyprus and Athens see especially Raptou 1999, 15-131; Raptou 2016. 
at the end of the Cypriot Revolt (498 BC) and during the Persian Wars. Then, I will give a chronological overview of the incidents known from Cypriot history in the 5 th century BC. Finally, I will try to define the role of Cyprus in these conflicts and to assess the potential influence of the Cypriot kings on politics of that time.

\section{Cyprus in 497 BC: The Relationship with Persia at the End of the Cypriot Revolt}

Since at least Archaic times to the late 4th century BC, Cyprus had been divided into several small kingdoms, around ten, though their number varied. The most important of these were Salamis on the Eastern coast, Kition, Amathus and Paphos on the southern coast, as well as Soloi and Marion in the northwest of the island. The rich copper deposits, found on the slopes of the huge Troodos Mountains in the western part of the island, were of major importance for the economies of these small states. Hence, conflicts arose between the kingdoms fighting to gain access to the copper mines and/or harbours in order to ship the copper overseas. In the course of these conflicts, the inland states of Idalion and Tamassos began to lose their importance. ${ }^{7}$

The population of the island consisted mainly of Greeks who had settled on the island at the end of the Bronze Age, but there was also a strong Phoenician element, especially in Kition, where a Phoenician dynasty ruled at least in the 5th and 4th centuries BC. Furthermore, one or several autochthonous languages seem to have been in use on the island, referred to by scholars as "Eteo-Cypriot."

By the end of the 6th century BC, Cyprus had become part of the Persian sphere of influence. The Cypriot monarchs had submitted to the Great King Cambyses. ${ }^{9}$ As in earlier times, when the Assyrian monarchs had been the suzerains of the islands, the Cypriot petty kings had to pay tributes and provided military support, for example for Cambyses' campaign against Egypt. Nevertheless, the Persians left the Cypriot monarchs in power in their own realms: they were allowed to rule their kingdoms and to mint their own coins. They were even able to follow their own foreign policies, as long as these did not collide with Persian interests.

The relationship of the Cypriot kings to their Near Eastern masters (first the Assyrians, later the Persians) can be explained by the concept of suzerainty: the petty kings submitted to a stronger monarch, accepting certain conditions, such as the paying of tributes and providing of military support when required. On the other hand, they were able to keep their positions as well as control over their kingdoms. The Cypriot kings profited from this act of submission, since it allowed them to keep access to the important

7 These topics have been treated thoroughly by Maria Iacovou in several articles; Iacovou 2002, 75-85; Iacovou, in: Peltenburg - Iacovou 2012, 358; Iacovou 2013, 31-32; see further Körner 2017, 55-56.

8 Pseudo-Skylax (103) mentions in his Periplus (dating from the 4th century BC) the existence of an autochthonous population on the island. Some of the inscriptions found on Cyprus cannot be read and might stem from these indigenous groups. But one should be very cautious about identifying them as "ethnic groups" and rather refer to them as "linguistic groups," see Iacovou 2006, 42-44; Körner 2017, 75-77; 90-91.

9 Hdt. 3.19.3; according to Xenophon (Cyrop. 7.4.1-2; 8.6.8), the Cypriot kings had already accepted Persian suzerainty under Cambyses' father Cyrus. 
markets on the Levantine coast. The relationship between masters and servants could change, depending on the strength of the superior monarch's position: when the Persian king was in a weak position or occupied by problems in other territories, a petty king could try to act in a more self-confident manner. Another characteristic in the relations between the petty kings and their Persian masters was an immanent potential of rivalry among the Cypriot rulers: in conflicts on the island, the Great King could support one kingdom against another. This policy of divide-et-impera (divide-and-rule) helped him keep control over the region. Hence, a certain instability was inherent in this relationship of suzerainty, which occasionally resulted in misunderstandings and conflicts between the petty kings and their masters. ${ }^{10}$

In 498 BC, a revolt broke out in Cyprus, starting in Salamis, the most important kingdom on the island. ${ }^{11}$ The cause of this revolt seems to have been an inner conflict in the ruling house of Salamis: Onesilus, the brother of king Gorgus, had tried to convince the latter to join the Ionian rebellion. When Gorgus remained faithful to the Persian king, he was dethroned by Onesilus. While Gorgus was seeking help with the Persians, Onesilus was able to unite all the island's kings - except for Amathus - and to gain help from the Ionians who sent a fleet of ships. Nevertheless, in the final battle at Salamis, Onesilus' land forces and his Cypriot allies were defeated when Stasanor, king of Kourion, decided to change sides. ${ }^{12}$ The Persians then reasserted domination of the whole island: "So the Cyprians, after winning freedom for a year, were enslaved once more,"13 as Herodotus concludes in his digression on Cypriot affairs.

What was the situation of Cyprus at the end of the Cypriot Revolt? Apparently, the system of suzerainty was restored. Gorgus was reinstated in Salamis. ${ }^{14}$ Some scholars surmise changes in the ruling dynasties in several Cypriot cities. In Kition for example, no kings have been confirmed before the 5th century BC. According to Maria Iacovou, the Phoenician dynasty of Ba almilk I may then have been established in Kition. ${ }^{15} \mathrm{Nev}$ ertheless, the Persians seem not to have altered the relationship between the Cypriot kings and their masters. ${ }^{16}$ Apparently, they more or less accepted the status quo from before the revolt. ${ }^{17}$ And the Cypriot monarchs resumed their duties: when, in the same year, the Persian army attacked Milet to suppress the Ionian Revolt, it also included Cypriot ships in its fleet. ${ }^{18}$ Seventeen years later, the Cypriot kings are again confirmed as loyal supporters of Persia: according to Herodotus, they sent 150 ships for Xerxes' fleet when

10 This concept is further developed in Körner 2016, 32-33, 40-45, and Körner 2017, 171-181.

11 Herodotus (5.104-116) is the only literary source for the Cypriot Revolt. For an interpretation of the revolt see Körner 2016, 33-36; Körner 2017, 202-223.

12 According to Herodotus (5.112.1), at least the Ionians were victorious in the sea battle, but sailed home after the defeat of the Cypriot land forces (5.115.1).

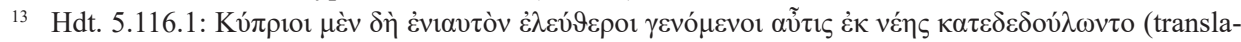
tion by A. D. Godley).

14 Hdt. 5.115.1.

15 Iacovou 2006, 49-50; see also Papantoniou 2012, 108-109.

16 It also seems improbable that the Persians established permanent garrisons on the island. Persian garrisons in Cyprus are referred to only twice: Diod. 11.44.2 and 12.4.1. Therefore, their existence is questioned by most scholars; see the discussion in Zournatzi 2005, 45-46, 64-65.

17 Körner 2017, 216-223.

18 Hdt. 6.6. 
he attacked Greece in $480 \mathrm{BC}$. Compared with the numbers of ships from Phoenicia and Syria (300) and from Egypt (200), the Cypriot contingent was the third-largest in the Persian fleet. ${ }^{19}$ Herodotus even provides several details: twelve ships came from Paphos under the command of a man named Penthylus; eleven of these got lost in a storm while the last one, with Penthylus aboard, was captured by the Greeks before the naval battle of Salamis. The Salaminian detachment was led by king Gorgus and his brother Philaon (who was taken prisoner by the Greeks in the battle at Artemision). ${ }^{20}$

Therefore, by the time of the Persian Wars, Persian suzerainty over Cyprus seems to have been firmly in place again. Of course, Xerxes had to rely on a secure hinterland for his naval campaign against the Greek mainland. Thus, it is highly improbable that Persian control over the island was weak in $480 \mathrm{BC}$. And it seems that the Cypriot kings accepted this situation for the time being: for the next 100 years, until the outbreak of the Cypriot War around $380 \mathrm{BC}$, we do not know of any action taken by a Cypriot king against Persia. ${ }^{21}$ Nevertheless, the island is mentioned several times in the conflicts between Athens and Persia. Furthermore, we have one reference to an inner-Cypriot conflict involving the Persians as well. What were the reasons behind these conflicts? And what was the role played by Cyprus in it? In order to answer these questions, we first have to see what is mentioned in the sources about these incidents.

\section{Greek Interventions in Cyprus Between the Persian Wars and the Peloponnesian War (479-432 BC)}

"Of Erechtheis, these died in the war, in Cyprus, in Egypt, in Phoenicia, in Halieis, in Aigina, at Megara in the same year." ${ }^{22}$ With these two lines begins the already mentioned inscription of the Athenian phyle Erechtheis, listing those who had fallen in campaigns in the year 460/459 BC. The first place mentioned is Cyprus, followed by the adjacent regions of Egypt and Phoenicia while the three cities that follow lie in mainland Greece. But which conflicts led the Athenians to intervene in Cyprus? And how does this intervention fit into their wider political schemes in the region?

In order to answer these questions, we have to rely on other writings, some much later. The most important source is Thucydides. The Athenian historian lived in the 5th century BC and, as an actual participant in the Peloponnesian War, had insight into Athenian politics of the times. Of course, his survey of the years before the Peloponnesian War takes an Athenian point of view. Cyprus is mentioned only when it is of interest to his Athenian perspective. Nevertheless, his text has the great advantage of being written by someone close in time to the events.

19 Hdt. 7.90; see also Diod. 11.3.7.

20 Hdt. 7.98 (Gorgus; here, Herodotus mentions also a commander named Timonax, without specific indication of his place of origin in Cyprus); 7.195 (Penthylus); 8.11.2 (Philaon), 8.100.4; Diod. 11.19.1-2 (Cypriot ships in the battle of Salamis).

21 According to the Bronze Tablet of Idalion (ICS, no. 217), the Persians and the Kitians besieged Idalion. But there is no indication that the Idalian king Stasikypros had taken any action against Persia; see below chapter 3.

22 $I G \mathrm{I}^{3} 1147$ (see footnote 2). 
Another important, albeit often very problematic source is Diodorus: his universal history was written much later than the events considered here, in the 1 st century BC. Apparently, the main source for most of what Diodorus writes about the 5th and 4th centuries BC was Ephorus of Kyme who lived in the 4th century BC. ${ }^{23}$ In Diodorus' voluminous universal history, Cyprus is, of course, not the focus of attention. Sometimes, his account is confused, particularly, as we shall see, in his (or Ephorus') descriptions of Cimon's interventions in Cyprus.

In addition to these main sources, further evidence can be gained from later literary traditions: especially Plutarch, in his biographies on Athenian politicians as Cimon, provides important information. Plutarch lived much later (1st century AD), but he used several sources from the 5 th and 4 th century BC. What makes his texts important for modern scholarship is the fact that he often names his sources, especially when they offer different information on his topics. Since most of Plutarch's sources have been lost, his biographies have preserved at least fragments of what once was there. Besides Ephorus, Plutarch also made use of Callisthenes (4th century BC) whose Hellenika, dedicated to the history of the 4th century $\mathrm{BC}$, also seem to have included brief reviews on earlier times. ${ }^{24}$ Another author used by Plutarch is Phanodemus (4th century BC) whose lost work Atthis dealt with the death of Cimon. ${ }^{25}$

Some information can also be gathered from the portraits of Cimon and Pausanias written in Latin by Cornelius Nepos (1st century BC) and from the lexicon entry dedicated to Cimon in the Byzantine Suda (10th century AD). These texts are very short though, especially when compared to Diodorus' lengthy accounts.

One problem common to all literary sources is their Athenian perspective ${ }^{26}$ : Cyprus is never the focus of their attention but serves only as the background for a description of Athenian activities in the Eastern Mediterranean. Nevertheless, from these various texts written over several centuries, we can reconstruct at least four Greek interventions with Athenian participation that affected Cyprus in the 5th century BC.

The first intervention dates to immediately after the Persian Wars and is contained in Thucydides, Diodorus and a short note by Nepos. It was not an operation by the Athenians alone, but a joint venture of the victorious Greeks: the Spartan Pausanias arrived in Cyprus in $478 \mathrm{BC}$ with a fleet combining Peloponnesian and Athenian ships, freeing the island from Persian suzerainty. ${ }^{27}$ This intervention was part of Pausanias' actions taken after the Persian Wars and performed in order to expel the Persians from the Aegean islands and obviously also from Cyprus. According to Diodorus, it was Aristides who was in command of the Athenian ships. ${ }^{28}$

23 Lendle 1992, 140-141; Hornblower 1994, 37; Luce 1997, 109; Stylianou 1998, 49-50.

24 Lendle 1992, 155-156.

25 Lendle 1992, 147.

26 See also Zournatzi 2005, 13.

27 According to Raptou (1999, 244), the Greeks might have reacted to a call for help from Cyprus. Since Aeschylus mentions Paphos, Soloi and Salamis in his play "The Persians" (892-896), staged in 472 BC, Stylianou $(1992,439)$ and Raptou $(1999,244)$ suppose that these three kingdoms had freed themselves again from the Persian suzerainty and were looking for support in Athens.

28 Thuc. 1.94; cf. 1.128.5; Diod. 11.44.1-2; Nepos, Paus. 2.1. According to Thucydides and Diodorus, the Athenians provided 30 ships. The Peloponnesian share was either 20 (Thucydides) or 50 ships (Diodorus). Aristides is only mentioned by Diodorus. Diodorus lists the intervention as occurring in the year 477/476 BC, 
This raises the question of whether some of the Cypriot kingdoms might have joined the Athenian League when it was established in order to fight the Persians. ${ }^{29}$ There are several arguments against this hypothesis: no source ever mentions the membership of a Cypriot state, especially not the Athenian tribute lists. On the other hand, Cypriot ships have been attested to as part of the Persian fleet several times, and, as we shall see, the Athenians had to intervene in Cyprus at least three more times until 449 BC. Of course, it remains possible that some of the Cypriot states joined the League, but the lack of evidence is a strong argument against such an assumption.

Apparently, the liberation of Cyprus did not last for long: about ten years later, Cypriot forces are yet again referred to as part of the Persian fleet. Diodorus delivers a long, unfortunately not very trustworthy account of several incidents, all of which he dates to the year $470 / 469 \mathrm{BC} .{ }^{30}$ Nevertheless, his account shall serve as starting point for my analysis, since it is the longest passage referring to Athenian politics in Cyprus; I will then compare it with other sources in order to reconstruct this second intervention.

Diodorus' account starts with the election of Cimon as $\sigma \tau \rho \alpha \tau \eta \gamma$ ó $\varsigma$ in order to wage war in Asia and liberate the cities still under Persian control. After his first moves at Eion and Scyrus, Cimon focussed on Caria. In the meantime, the Persians gathered their forces on land and at sea. The Persian naval forces came from Phoenicia, Cyprus and Cilicia. ${ }^{31}$ Therefore, Persia had obviously regained control over Cyprus, or at least over some of the kingdoms. ${ }^{32}$ According to Diodorus, Cimon first defeated the Persians near Cyprus. He then carried on to the coast of Asia Minor where he gained a second victory on the banks of the Eurymedon river, an event depicted vividly by Diodorus. ${ }^{33}$ Afterwards, the Athenians set up a dedication commemorating Cimon's victories. ${ }^{34}$

Diodorus' whole account is highly problematic: obviously he (or his source Ephorus) conflated several incidents spanning more than a decade in his narrative of the year 470/469 BC. The Athenian dedication and accompanying epigram should be dated several years later (see below). The naval battle which, according to Diodorus, took place in Cyprus seems to be a duplication of the Athenian victory at the river Eurymedon. ${ }^{35}$

but it should rather be dated at 478 BC: see Will's commentary in: Diodoros 1998, 313. According to Stylianou $(1992,441)$, a coin hoard found in Kition might point to a siege of this town during this intervention.

29 Some scholars deem it possible: Meiggs, 1972, 56-58, 65, 486; Stylianou 1992, 441-444, who even thinks that the Cypriot states might have been members of the League from the beginning; against the assumption: Tuplin 1996, 44-45; cautious: Raptou 1999, 245.

30 Diod. 11.60-63.

31 Diod. 11.60.5. Diodorus' source here is Ephorus, as can be reconstructed from Plutarch: Plutarch (Cim. 12.4) states that according to Ephorus ( $F G r H$, no. 70, F192), Tithraustes was the general of the Persian army, while according to Callisthenes ( $F G r H$, no. 124, F15), a certain Ariomandes commanded the Persian troops. Since Diodorus only mentions Tithraustes, he must have used Ephorus in this passage.

${ }^{32}$ A passage in Thucydides' work may be interpreted as referring to a retreat of the Greek forces from

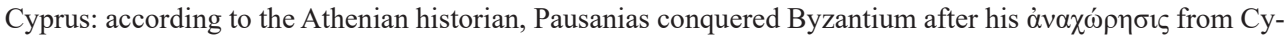

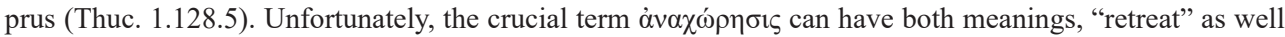
as "return." G. P. Landmann in the German version translates "Rückzug" ("retreat"), while C. F. Smith in the English translation uses the term "return."

33 Diod. 11.61.

34 Diod. 11.62 .3 (see footnote 3).

35 Diod. 11.60.6. See Will (in Diodoros 1998, 318) who thinks the error may already have been Ephorus'. For the discussion of dating the battle at the Eurymedon, see Badian 1987, 3. 
This becomes clear from Plutarch's much more concise account, according to which the naval battle as well as the destruction of the Persian camp and decimation of its land forces took place at the Eurymedon. Plutarch's account is more trustworthy than Diodorus', also because the former mentions and meticulously compares several sources, all dating from the 4th century BC. ${ }^{36}$ After a short discussion of the question of who was in command of the Persian troops, Plutarch follows Callisthenes: the Persian army had camped at the mouth of the Eurymedon and waited for 80 Phoenician ships to arrive from Cyprus. The island therefore must have been at least partially on the Persian side again since it could serve as their naval base. According to Plutarch, Cimon then set sail to the Eurymedon in order to arrive there before the Phoenician ships coming from Cyprus. He forced the Persian fleet to fight and defeated it. Afterwards, his troops landed and vanquished the Persian land forces. In a third battle, he also defeated the 80 Phoenician ships. In Plutarch's account, all battles are located at or near the mouth of the Eurymedon. Also, all other sources place the double victory at sea and on land here. ${ }^{37}$

What can be deduced with certainty is that Cyprus served as a foothold for the Persian fleet once again; this is also made explicit by Plutarch. ${ }^{38}$ Unfortunately, no source mentions what happened after the defeat of the Persians at the Eurymedon: was Cyprus freed again? ${ }^{39}$ That the situation in the Eastern Mediterranean remained fragile and prone to conflicts can be deduced from the aforementioned inscription for the fallen soldiers of the phyle Erechtheis, dated 460/459 BC: it proves that ten years later there were Athenian military actions on Cyprus as well as in Egypt and Phoenicia. ${ }^{40}$ The cause of the inscription seems to have been a third Athenian intervention on Cyprus, also attested to by Thucydides and Plutarch: Athens sent 200 ships to aid Inarus II of Egypt against Persia. Egypt had been part of the Persian Empire since the days of Cambyses. At the time, Inarus had revolted successfully and was seeking aid against Persia. The Athenians had already dispatched 200 ships to Cyprus which were then redirected to Egypt. ${ }^{41}$ As the inscription shows, military actions must also have taken place in Cyprus. This seems to indicate that Cyprus was either not freed completely by Cimon after the battle of Eurymedon or that the Persians had once again regained control.

The last Athenian intervention in Cyprus mentioned in the sources is probably the most famous since it resulted in Cimon's death on the island. Again, Diodorus' account

36 Plut., Cim. 12.4 and 12.5 (Ephorus, FGrH, no. 70, F192), 12.4 and 13.5 (Callisthenes, FGrH, no. 124, F15 and 16), 12.5 and 19.1 (Phanodemus, FGrH, no. 325, F22 and 23).

37 Plut., Cim. 12.4-13.2; Suda, K 1620, https://www.cs.uky.edu/ raphael/sol/sol-entries/kappa/1620 (accessed: 2 February 2020). The two victories at sea and on land at the Eurymedon are also mentioned by Thucydides (1.100.1), but without connection to Cyprus or Cypriots. Nepos (Cim. 2.2) refers to a double victory of Cimon (one of them by sea over 200 Cypriot and Phoenician ships), but places it at Mycaleobviously confusing the battle at the Eurymedon with the battle at the Mycale-peninsula in 479 BC: see Anselm 2004, 90.

38 Plut., Cim. 12.4 .

39 Diodorus (11.61.7) mentions only that Cimon returned to Cyprus. Nothing is said about any further actions taken there by the Athenian general.

$40 I G \mathrm{I}^{3} 1147$ (see footnote 2); Zournatzi 2005, 13, note 7.

41 Thuc. 1.104.2; cf. Plut. Them. 31.3. See Meiggs 1972, 92-93. A short notice by Isocrates in his speech on peace (8.86) and a remark by Aelianus (var. hist. 5.10) may also refer to this event since they give the same number of ships dispatched to Egypt (200) as Thucydides. 
is by far the longest. ${ }^{42}$ And unfortunately, it is again the most problematic. The Sicilian historiographer starts his twelfth book with the Athenian campaign against Cyprus. $\mathrm{He}$ dates this event to the year $450 / 449 \mathrm{BC} .{ }^{43} \mathrm{Cimon}$ was once again made general and sailed his fleet into the Eastern Mediterranean. On the Persian side, Artabazus commanded the ships at anchor in Cyprus, while Megabyzus stayed in Cilicia with the Persian land forces. ${ }^{44}$ According to Diodorus, Cimon besieged Marion and Kition, then defeated a fleet arriving from Cilicia and Phoenicia. He pursued the rest of the Persian ships back to Phoenicia. The Persian fleet then escaped to the land forces under Megabyzus' command, obviously still in Cilicia (although the region is not mentioned anymore). The Athenians landed and defeated the Persian army, then sailed back to Cyprus. According to Diodorus, this all happened within the same year. ${ }^{45}$

The historiographer continues his narrative with events he dates to the following year: Cimon conquered the cities of Cyprus. Salamis remained the main Persian base and was held by a Persian garrison. ${ }^{46}$ According to Diodorus, Cimon then followed the strategy of destabilising the Persians' reputation and influence by trying to conquer this stronghold. He besieged Salamis. ${ }^{47}$ Realising his predicament, Artaxerxes instructed his generals and satraps to negotiate a peace treaty with the Greeks. Artabazus and Megabyzus came to terms with the Athenians, who were represented by their ambassador Callias. According to the treaty, all Greek cities in Asia were freed, the Persian satraps being required to stay away from the sea. The Persian fleet was not allowed to sail beyond Phaselis and the Cyanean Rocks. On the other side, the Athenians were made to accept the Persian sphere of influence. Consequently, they withdrew from Cyprus. Cimon later died here from natural causes. ${ }^{48}$

Diodorus' account has many ambiguities, errors and contradictions: first, Diodorus claims that the Persian fleet under the command of Artabazus was based in Cyprus. However, when Cimon landed in Cyprus, nothing is said about what happened with the 300 Persian triremes. Instead, Diodorus writes that the ships arrived from Cilicia and Phoenicia. Next, it is strange that the Persian ships first seek refuge in Phoenicia and then seem to carry on to Cilicia which, being much nearer to Cyprus, would have been the perfect refuge in the first place, especially since the Persian land army was based there. Obviously, Diodorus or his source Ephorus ${ }^{49}$ confused the events of $450 \mathrm{BC}$ with the battle at the Eurymedon which had taken place 20 years earlier. On the other hand, the Athenian dedication commemorating a victory which Diodorus places in the context of the battle at the Eurymedon (see above) would make a better match with the skir-

42 Diod. $12.3 \mathrm{f}$.

43 For Diodorus' dating see Will's commentary, in: Diodoros 1998, 325.

44 Diod. 12.3.2.

45 Diod. 12.3.3-4.

46 For the question of the existence of Persian garrisons in Cyprus, see above footnote 16.

47 Diod. 12.4.1-3.

48 Diod. 12.4.4-6.

49 According to Badian $(1987,15)$, Diodorus, not Ephorus is to be blamed for the confusion. 
mishes in the context of the fourth campaign. ${ }^{50}$ Accordingly, Diodorus' account has been much criticised for confusing several incidents. ${ }^{51}$

As Meiggs has already observed, the epigram on the Athenian dedication cited by Diodorus/Ephorus is of special importance, since it seems to preserve a testimony contemporary to the events: the text mentions an overwhelming double victory on land and at sea, in which the Athenians were able to capture a 100 ships. ${ }^{52}$ This fits the description of Thucydides who also mentions an Athenian double victory during the fourth intervention. The Athenian contemporary historian must have had access to much more reliable information concerning the events in Cyprus that led to Cimon's death. As Thucydides makes clear, the expedition was intertwined again with war in Egypt: the new Egyptian pharaoh, Amyrtaeus, had asked for Athenian help and received 60 ships. ${ }^{53}$ Cimon then laid siege to Kition and died from a disease during the siege. When a famine threatened the Athenian army, the soldiers left the island, but were still able to fight a battle against an army and fleet of Cypriots, Phoenicians and Cilicians at Salamis. ${ }^{54}$

In his biography of Cimon, Plutarch provides a similar account. The Athenian general sailed to Cyprus and dispatched 60 ships to help the Egyptians against the Persians. He defeated a fleet of Phoenician and Cilician ships and then subdued the island. ${ }^{55}$ While besieging Kition, Cimon died either from a disease or from a wound. Before his death, he advised his soldiers to keep his death a secret and to sail home. ${ }^{56}$ Plutarch then offers two versions about what happened to Cimon's body: either it was brought to Athens or it remained in Kition, since, according to Nausicrates the rhetorician, the people of Kition honoured Cimon's tomb in their city. ${ }^{57}$

What can be said with certainty is that in the middle of the 5 th century BC, Cimon led another attack against Cyprus. Obviously, the island was still under Persian control.

50 Diod. 11.62.3; see Meiggs 1972, 127; Badian 1987, 15; Will, in: Diodoros 1998, 318; see also the discussion in Barns 1953, 167-169.

${ }^{51}$ See especially Will, in: Diodoros 1998, 325, and the systematic overview in Meister 1982, 26-30; see also Parker 1976, 31; Stylianou 1992, 453-456.

52 Diod. 11.62.3 (see footnote 3); Meiggs 1972, 127.

53 Thuc. 1.112.2-3. Isocrates (8.86) and Aelianus (var. hist. 5.10) may also refer to this Athenian intervention in Cyprus: according to them, 150 Athenian ships were engaged in Cyprus. Since Thucydides mentions 200 ships being sent to Cyprus, and 60 of these 200 being further dispatched to support Amyrtaeus of Egypt, 140 ships would have been left in Cyprus, which would approximately correspond to the number of 150 ships given by Isocrates and Aelianus. Nevertheless, both passages are only very short lists of Athenian troops engaged in wars and therefore cannot be connected with this intervention with certainty.

54 Thuc. 1.112.4. Thucydides's text is rather short here so the cause of Cimon's death remains unclear:

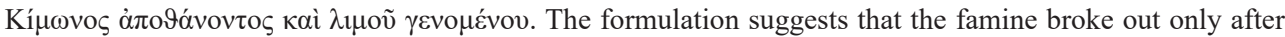

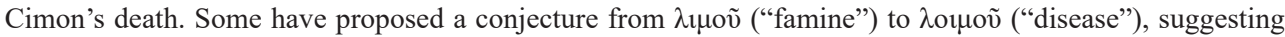
that Cimon would have died from a disease. But the conjecture would not make things clearer, since the disease would have broken out only after Cimon's death as well: for the whole question, see Badian 1987, 39 .

55 Plut. Cim. 18.1-2; 4-5.

56 Plut. Cim. 19.1. Plutarch (Cim. 18.2-4; 6-7.) describes several omens prophesising Cimon's death. In his Pericles-Vita, Plutarch briefly mentions Cimon's death in Cyprus (Plut. Per. 10.7).

57 Plut. Cim. 19.4. As has already been observed by Raptou (1999, 249, note 50), the tradition of revering a former enemy as a superior being is also known from Amathus: Onesilus, king of Salamis, had besieged the city during the Cypriot Revolt. After his death, the Amathusians hung his head on the city wall. When they later received an oracle, they buried the head and revered Onesilus as a hero, offering yearly sacrifices to him: Hdt. 5.114. 
It remains unclear, whether Cimon was able to conquer Kition or not. ${ }^{58}$ At the very least, he must have established a firm stronghold on the island in order to be able to launch another attack against the Persians in Egypt. The two sources nearest to the events, the epigram and Thucydides, both refer to an overwhelming victory of the Athenians, both on land and at sea. The Athenians were able to defeat a fleet of Phoenician, Cilicians and Cypriots. Thucydides' remark that the hostile fleet also included Cypriot ships shows clearly that not all Cypriot cities had come under Athenian influence. All further strategic plans were cut short by Cimon's untimely death, either from a disease or from a wound. ${ }^{59}$

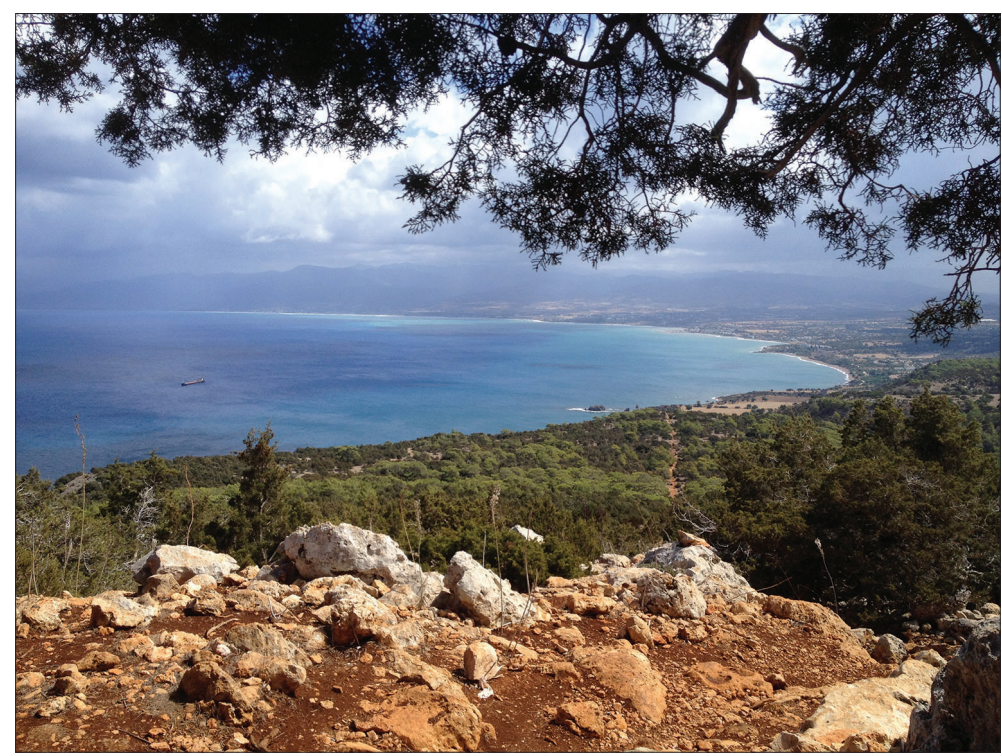

Fig. 1. The bay of Marion (modern Polis) in northwest Cyprus

(Photo by: C. Körner, September 2014)

While Diodorus' account has many errors, the capture of Marion, mentioned only by him, still may be historical: the bay of Marion (today Polis, Fig. 1) on the extreme northwestern coast of Cyprus was a perfect place for an Athenian fleet arriving from the Aegean, far away from the hostile cities of Kition and Salamis where battles were fought

58 Nepos (Cim. 3.4), Aristodemus (FGrH, no. 104, F13.1, who also mentions the naval victory of the Athenians) and the Suda (K 1620, https://www.cs.uky.edu/ raphael/sol/sol-entries/kappa/1620, accessed: 2nd February 2020) have Cimon die in the city of Kition, not during its siege. This would indicate that the siege was successful.

59 One would prefer to follow here the nearly contemporary account of Thucydides (1.112.3-4) who places Cimon's death before the victory at Salamis, rather than the later description given by Plutarch (Cim. 18.5) who has his hero Cimon win the decisive battle in Cyprus (which Plutarch does not locate at Salamis). 
later. ${ }^{60}$ Also, Marion is not a very common place in Greek historiography, so one cannot easily think of a reason for possible confusion by Diodorus/Ephorus. ${ }^{61}$

After Cimon's death, no further Athenian interventions on Cyprus are mentioned in the sources. Since Thucydides provides an account of Athenian history before the outbreak of the Peloponnesian War, he would probably have mentioned further conflicts between Athens and the Persians in the Eastern Mediterranean. Therefore, hostilities between them must have already ceased. According to Diodorus, the clauses of the socalled "Callias Peace" forbade the Persians to sail further than Phaselis in Lycia which would have placed Cyprus on the Persian side. Even though the "Callias Peace" may not have been authentic, at least, the spheres of influence between Persia and Athens were clearly defined. ${ }^{62}$

While Diodorus' description of events may be highly problematic, it is still of value. It delivers an insight into the importance of Cyprus in the conflicts between Athenians and Persians: it was not only the geographic position of the island that made it a perfect base for operations in the Eastern Mediterranean. According to Diodorus, Cimon also wanted to subdue the whole island in order to undermine the Great King's position with his allies. ${ }^{63}$

To sum up: Greek - especially Athenian — interventions in the Eastern Mediterranean affected Cyprus at least four times in the years between 480 and 450 BC. The interventions were often connected with struggles in Egypt (which had freed itself from Persian domination), Asia Minor and Phoenicia. The only Cypriot kingdoms ever mentioned in the sources concern the fourth intervention: Kition (besieged and perhaps conquered), Salamis (battleground) and-more uncertainly-Marion (conquered).

Before we try to further assess the role of the Cypriot kingdoms in these struggles, we have to take a look at the only evidence from the island itself concerning conflicts in the 5 th century BC: the Idalian Tablet.

\section{The Siege of Idalion by Kition and Persia—a Persian Intervention?}

"When Medes and Kitians besieged the city Idalion in the year of Philokypros, (the son) of Onasagoras": these words are the beginning of the longest inscription in the Cypriot syllabary, the so-called "Bronze Tablet of Idalion." 64 It was set up in the sanctuary of Athena which lay on the western acropolis of the city. ${ }^{65}$ The text of the tablet refers to a donation made by King Stasikypros and the polis of Idalion to a family of doctors who

60 Parker 1976, 36.

61 As far as I know, the capture of the city by Cimon is the first historical event recorded for Marion. Athenian cultural influence on Marion is visible in the archaeological records, especially in the Attic pottery found in the cemeteries: Meiggs 1972, 480; 483-484; Raptou 1999, 25-27.

62 The authenticity of this peace has been hotly debated since the 4th century BC, see Meiggs 1972, 129-151, 489-495; Meister 1982, 32-94; Badian 1987, 1-37; Stylianou 1992, 445-449.

63 Diod. 12.4.1-2.

64 ICS, no. 217 (see footnote 4).

65 See Georgiadou 2010, 144. 
had taken care of the wounded during the siege. ${ }^{66}$ Obviously, the siege was not successful, otherwise King Stasikypros and his polis would not have been able to erect a dedication which emphasizes in its very first lines Kition's attack on Idalion.

Unfortunately, the siege cannot be dated exactly. ${ }^{67}$ There is at least a terminus ante quem: Although the siege had been unsuccessful, Kition was nevertheless later able to annex Idalion. This is proven by the royal titles: the kings of Kition ruling in the second half of the 5th century and in the 4th century BC bore the title "King of Kition and Idalion." The first Kitian king to do so was 'Oziba' al whose reign seems to have started after $445 \mathrm{BC}$, according to a coin hoard find. ${ }^{68}$ So, the siege mentioned in the tablet must have taken place in the first half of the 5 th century BC. ${ }^{69}$

The text offers the only immediate insight into the conflicts of the 5th century BC which must have taken place on the island. Unfortunately, the role of the Persians in this enterprise is less clear. The text does not clarify the reasons for the Persian-Kitian collaboration in the siege. The model of suzerainty, however, might help explain the situation: local conflicts between petty kings on the periphery were accepted as long as they did not affect Persian interests. In $411 \mathrm{BC}$, Evagoras I was able to overthrow the ruling monarch of Salamis although the latter was a friend of the Great King. Obviously, this coup was accepted by the Persians. Afterwards, Evagoras proved himself a loyal supporter of Persia for 20 years. He was even able to expand his power on the island for some time, before the Great King finally intervened - and only after an appeal for help from Amathus, Kition and Soloi. ${ }^{70}$

The political fragmentation on the island facilitated Persian control, since it gave Persia the possibility to support one small kingdom against another - or even intervene in conflicts in a ruler's house, as in Salamis during the Cypriot Revolt. This divide-andrule-policy was of major importance for Persian rule on the periphery of its empire. ${ }^{71}$ This might also be the reason for the Persian-Kitian collaboration in the siege of Idalion: the king of Kition had probably proven himself a loyal subject and so received the support of the Great King. The fact that the siege was unsuccessful and that King Stasikypros and his polis were able to set up the Bronze Tablet in the sanctuary of Athena also makes clear that the Persians had accepted their defeat.

The question remains whether the siege of Idalion was the consequence of one of the conflicts between Athens and Persia in the 5th century BC. Idalion is never mentioned in any of the literary texts dealing with Athenian interventions that had affected Cyprus. As an inland territory, it was of minor importance for Athenian warfare which concentrated

66 We will leave aside here the constitutional implications of the formula "king and polis," a muchdebated topic in Cypriot history; see Georgiadou 2010, 170-183; Körner 2017, 333-345; Körner, forthcoming.

${ }_{67}$ For an overview of the opinions raised in the scholarship see Masson, in: ICS, 238; Stylianou 1992, 403-404; Egetmeyer 1993, 40-41, note 4; Zournatzi 2005, 21-22, note 31; and especially the thorough discussion in Georgiadou 2010, 159-170.

$68 I G C H$, no. 1482. See Meiggs 1972, 484-485; Georgiadou 2010, 166.

69 Since the tablet was set up in the temple of Athena (ICS, no. 217, ll. 27-28; see Georgiadou 2010, 149 , note 18), the date of the latter's destruction constitutes a terminus post quem for the tablet (Stylianou 1992, 403). Unfortunately, archaeologists' views on the question of when the temple was destroyed differ, see Tuplin 1996, 45, note 92, and the discussion in Georgiadou 2010, 162-164.

70 Diod. 14.98.1-2; Ephorus, FGrH, no. 70, F76.

71 Wiesehöfer 2000, 155; Zournatzi 2005, 72; Körner 2017, 192-196. 
on ports such as Kition, Salamis and Marion. Idalion cannot have been a major target of Athenian politics. Therefore, the siege must rather have resulted from the inner conflicts of the island itself: Idalion was one of the inland polities which had access to the copper mines on the slopes of the Troodos mountains. Apparently, the kings of Kition wanted to gain access to these precious metal deposits. This also becomes clear from the fact that this siege was not the only attack on Idalion's independence: since the city later came under the rule of the kings of Kition, they must have eventually achieved their aim. The attack on Idalion must therefore have been instigated by Kition rather than by the Persians. That the text of the Bronze Tablet first refers to the "Medes," not to the Kitians, might be explained by the fact that the Persians constituted the more powerful and respected enemy.

Can we consider Persian military aid in the siege of Idalion an "intervention"? Of course, it was an intervention in as far as Persian troops operated on the island. But it cannot be compared with the four interventions in Cyprus which had their origins on the Greek mainland: these were dictated by Athenian, Egyptian and Persian interests in the Eastern Mediterranean. Cyprus was affected by them but never seems to have played any active part. We never hear of a Cypriot king appealing to the Athenians or the Persians for help. ${ }^{72}$ The siege of Idalion is a totally different matter: a result of inner-Cypriot conflicts, the Persian intervention was obviously caused by Kitian interests - and the relationship of suzerainty between the Great King and the Cypriot rulers.

\section{Conclusions: The Role of Cyprus in the Conflicts in the Eastern Mediterranean in the 5th Century BC}

Freilich wissen wir ja das Verborgene nicht und wollen nicht vergessen, daß Geschichte schreiben, auch wenn es noch so nüchtern und mit noch so gutem Willen zur Sachlichkeit getan wird, immer Dichtung bleibt und ihre dritte Dimension die Fiktion ist.

\section{Hermann Hesse, Das Glasperlenspiel}

Hesse's quote, taken from his last novel "Das Glasperlenspiel," describes a historian's work as an interplay between fact and fiction. This could also be applied to the dilemma of reconstructing Cypriot 5th century history. So many facts are hidden from view that trying to fill the gaps can easily lead to what Hesse calls the "third dimension": fiction.

This means that any conclusions must be drawn with a measure of caution. Still, our analysis of the little information preserved in the written evidence (table 1) allows us to establish at least a few essential facts of Cyprus' fate with regards to Athens and Persia in the 5 th century BC.

72 The assumption that Paphos, Soloi and Salamis might have called for help after the Persian Wars is a mere hypothesis (see above footnote 27 ). 
Table 1. Conflicts affecting Cyprus between the Persian Wars and the Peloponnesian War

\begin{tabular}{|c|c|c|c|}
\hline Date & Intervention & $\begin{array}{l}\text { Cypriot kingdoms } \\
\text { involved }\end{array}$ & $\begin{array}{l}\text { Sources mentioning } \\
\text { Cyprus in } \\
\text { chronological order }\end{array}$ \\
\hline Approx. 478/477 BC & $\begin{array}{l}\text { 1st intervention: } \\
\text { Sparta (Pausanias) and } \\
\text { Athens (Aristides) liberate } \\
\text { Cyprus }\end{array}$ & no indications & $\begin{array}{l}\text { - Thucydides } \\
\text { - Diodorus } \\
\text { - Nepos }\end{array}$ \\
\hline Approx. 470/469 BC & $\begin{array}{l}\text { 2nd intervention: } \\
\text { Athens (Cimon) defeats } \\
\text { the Persian army at the } \\
\text { Eurymedon; } \\
\text { Cyprus somehow involved; } \\
\text { Cypriots in the Persian fleet }\end{array}$ & no indications & $\begin{array}{l}\text { - Diodorus (after } \\
\text { Ephorus) } \\
\text { - Nepos } \\
\text { - Plutarch } \\
\text { (using Ephorus, } \\
\text { Callisthenes and } \\
\text { Phanodemus) } \\
\text { - Suda }\end{array}$ \\
\hline 460/459 BC & $\begin{array}{l}\text { 3rd intervention: } \\
\text { Athens sends ships to } \\
\text { Cyprus which then are being } \\
\text { dispatched to support Inarus } \\
\text { II of Egypt }\end{array}$ & no indications & $\begin{array}{l}\text { - IG } \mathrm{I}^{3} 1147 \\
\text { - Thucydides } \\
\text { - Isocrates? } \\
\text { - Plutarch } \\
\text { - Aelianus? }\end{array}$ \\
\hline 450/449 BC & $\begin{array}{l}\text { 4th intervention: } \\
\text { Athens attacks Cyprus; } \\
\text { siege of Kition and battle at } \\
\text { Salamis; } \\
\text { death of Cimon on the island }\end{array}$ & $\begin{array}{l}\text { Kition } \\
\text { Salamis } \\
\text { Marion (only } \\
\text { according to } \\
\text { Diodorus) }\end{array}$ & $\begin{array}{l}\text { - Simonides } \\
\text { - Thucydides } \\
\text { - Isocrates? } \\
\text { - Diodorus } \\
\text { - Nepos } \\
\text { - Plutarch } \\
\text { - Aristodemus } \\
\text { - Aelianus? } \\
\text { - Suda }\end{array}$ \\
\hline Before $445 \mathrm{BC}$ & $\begin{array}{l}\text { Siege of Idalion: } \\
\text { Persians and Kitians besiege } \\
\text { Idalion. }\end{array}$ & $\begin{array}{l}\text { Idalion } \\
\text { Kition }\end{array}$ & $-I C S 218$ \\
\hline
\end{tabular}

If we compare the four Greek interventions in Cyprus, it becomes clear that they all have one thing in common: no Cypriot kings are mentioned. We never hear of any Cypriot monarch beseeching the Athenians or the Persian Great King for assistance. No ancient source mentions an inner-Cypriot cause for any of the interventions. The fact that Cimon had to besiege Kition in 450/449 BC at least makes clear that this city stood firmly on the Persian side. If we trust Diodorus, then Marion and especially Salamis were also Persian allies, since they had to be besieged. Salamis is an interesting case: the most important city on Cyprus until the end of the 6th century BC and the origin of the Cypriot Revolt in $498 \mathrm{BC}$ is only mentioned in the context of the fourth Athenian expedition. Either it was besieged (according to Diodorus) or a naval battleground (according to Thucydides). It was only with the accession of Evagoras I around $411 \mathrm{BC}$ that the city 
became a powerful player again. Before Evagoras was able to seize power, Salamis was ruled by Abdemon of Tyros or Abdymon / Audymon of Kition, obviously a usurper who came from outside the city. ${ }^{73}$ This usurper had overthrown the regime of his predecessor, an unknown Phoenician who had dethroned the ruling dynasty of the Teucrids before. ${ }^{74}$ Around the time of the fourth Athenian expedition, Salamis could therefore have been ruled by this unknown Phoenician.

Be that as it may, we do not know anything about the political decisions on the Cypriot side. Apparently, Cyprus was the object of greater powers' interests. The Cypriot kings never played an active part in the politics of the 5th century BC; they seem to have been unable to take larger initiatives. I do not think that the blame for a lack of Cypriot names lies only with the sources and their distinctly Athenian perspective. Taking a look at the history of the 4th century $\mathrm{BC}$, we can see that Cypriot kings were able to play a much more important and active role in the politics and conflicts of the Eastern Mediterranean, especially Evagoras I of Salamis. ${ }^{75}$ This cannot be only a coincidence of sources, since they often have the same author: Diodorus (or his main source Ephorus) delivers most of the information concerning Cypriot kings of the 5th century as well as of the 4th century BC.

If we look for documents on the island, the only important source concerning conflicts in the 50 years between the Persian and the Peloponnesian Wars is the Bronze Tablet of Idalion. Here, at least, a king is mentioned: Stasikypros of Idalion whose city was attacked by Kitians and Persians. This confirms the view that Kition stood firmly on the Persian side. The siege of Idalion may very well have taken place in the aftermath of the fourth Athenian expedition: Kition could have received Persian aid against Idalion as remuneration for bearing Cimon's siege. But this must remain a mere hypothesis.

The war between Idalion and Kition was of a totally different character than the four Greek interventions. It has to be understood from two perspectives: first, it seems to have been a typical local conflict between two Cypriot cities, probably resulting from economic interests regarding the Idalian copper mines. Second, the involvement of the Persians suggests that the conflict must also be seen in the light of the relationship of suzerainty between Persian masters and Cypriot petty kings: conflicts between the Cypriot kings facilitated Persian control over the island since it enabled the Great King to support local kings against others in a policy of divide-and-rule. ${ }^{76} \mathrm{All}$ in all, the Bronze Tablet of Idalion does not contradict the overall picture that the Cypriot kings of the 5th century $\mathrm{BC}$ were not able to take initiatives outside of their island. And it is remarkable that the only Cypriot king mentioned in the context of a conflict in the 5th century $\mathrm{BC}$ after the Cypriot Revolt, Stasikypros of Idalion, is obviously not the one who took the initiative, but is rather seen in a passive role: he and his city were besieged. ${ }^{77}$

73 Abdemon of Tyros: Diod. 14.98.1; Abdymon / Audymon of Kition: Theopomp, FGrH, no. 115, F103.2.

${ }^{74}$ Isoc. 9.19-20.

75 For the Cypriot kings of the 4th century BC, see Körner 2017, 233-276; Körner 2020, 153-162.

76 Wiesehöfer 2000, 155; Körner 2016, 44; Körner 2017, 269.

77 Of course, the king of Kition besieging Idalion could be seen as a Cypriot monarch taking the initiative - his name is nevertheless not mentioned in the tablet's text. 
In the years between the Cypriot Revolt (498 BC) and the coming to power of Evagoras I of Salamis (around 411 BC), the Cypriot kings only took the initiative in conflicts on the island itself (Kition vs. Idalion). Conflicts in the larger context of the Eastern Mediterranean had their origins first and foremost in Athenian interests. Even the Persians seem to have been reactive rather than active: they got involved in Cyprus when asked by a local monarch (as in the Cypriot Revolt by Gorgos and probably in the attack on Idalion by the king of Kition).

But what were the interests of Athens in Cyprus? One key to this question may be found in the third and fourth campaign: both times, we hear of Egyptian requests for help; in the second Athenian intervention, the main battle took place at the Eurymedon in southern Asia Minor. Therefore, we can deduce that Cyprus was obviously of major importance for naval actions in the Eastern Mediterranean. ${ }^{78}$ And there were close commercial contacts between Athens and Cyprus in the 5th century BC. ${ }^{79}$ Cimon also seems to have hoped for a military success in order to weaken the Persian prestige with its allies. ${ }^{80}$ After all, Athens' attempts at political intervention were unsuccessful: the Athenians had to intervene again and again in Cyprus until 450 BC, without being able to establish a continuous control over the island.

All in all, the situation of Cyprus in the 5th century can be summed up as follows:

1. After the brutal end of the Cypriot Revolt, the Cypriot kings were able to retain their position, but for the next almost 90 years, they were unable to launch any larger initiatives.

2. Cyprus became a focus of interest in the conflicts between Athenians and Persians. This was due to its strategic position in the Eastern Mediterranean: often, the focus of wars was Egypt or Asia Minor, and Cyprus was important as a naval base for both opponents.

3. Until the middle of the 5th century BC, Athens was the most active party in the conflicts. The Persians often only reacted to Athenian attacks. Still, the Athenians were never able to establish permanent control over the island. After Cimon's death, Persian control over Cyprus seems no longer to have been questioned by Athens.

4. The local conflicts on the island between the Cypriot kingdoms themselves, which are characteristic for many centuries, must have carried on into the 5th century $\mathrm{BC}$ as well, although they are only mentioned by one source, the Bronze Tablet of Idalion. To a certain degree, the competition between the Cypriot rulers was in the interest of their Persian master, allowing him to control his subjects on the periphery. On the other hand, their conflicts could also affect Persian interests. This situation caused the Great King to intervene from time to time in order to restore his power or to remunerate a loyal ally.

78 Parker 1976, 32-34. The connection of Cyprus with Egypt in the Athenian strategy is also made clear in a short note by Plato (Menex. 241d-e).

79 Raptou 1999, 131-166; Mehl 2013, 142-149; Mehl, in: Zenzen - Mehl - van Ess 2013, 326-339; Raptou 2016.

80 Diod. 12.4.2. 
With Evagoras I of Salamis, this situation changed radically: this powerful monarch established a self-confident policy on the island and in the adjacent regions, which culminated in the Cypriot War (approx. 390-380 BC). Even before Alexander the Great created a totally new political landscape, the Eastern Mediterranean world had begun to change fundamentally during the 4 th century $\mathrm{BC}$, and Cyprus played a much more active part in this transition ${ }^{81}$ - a sharp contrast to the island's long hibernation during most of the 5 th century BC.

\section{BIBLIOGRAPHY}

\section{Sources}

Aelianus, Claudius, Varia historia, ed. by M. R. Dilts, Leipzig 1974.

Aeschylus, vol. 1: Persians. Seven against Thebes. Suppliants. Prometheus Bound, ed. and transl. by A. H. Sommerstein, Cambridge, Mass.-London 2008.

Diodoros, Griechische Weltgeschichte Buch XI-XIII, (Bibliothek der griechischen Literatur, vol. 45), transl. by O. Veh, comm. by W. Will, Stuttgart 1998.

Diodorus of Sicily, vol. 4: Books IX-XII 40, ed. and transl. by C. H. Oldfather, London-Cambridge, Mass. 1946 (repr. 1956, 1961); vol. 5: Books XII 41-XIII, ed. and transl. by C. H. Oldfather, London-Cambridge, Mass. 1950 (repr. 1956, 1961).

Herodotus, vol. 2: Books III and IV, ed. and transl. by A. D. Godley, Cambridge, Mass.-London 1921 (repr. 1928, rev. and repr. 1938, 1950, 1957, 1963, 1971); vol. 3: Books V-VII, ed. and transl. by A. D. Godley, Cambridge, Mass.-London 1922 (repr. 1928, 1938, 1950, 1957, 1963, 1971); vol. 4: Books VIII-IX, ed. and transl. by A. D. Godley, London-Cambridge, Mass. 1925 (repr. 1930, 1946, 1961).

ICS = Les inscriptions chypriotes syllabiques: Recueil critique et commenté (Études chypriotes, vol. 1), ed. by O. Masson, Paris 1961.

IG $\mathrm{I}^{3}=$ Inscriptiones Graecae, editio tertia, vol. 1, fasc. 2, ed. by D. Lewis, L. Jeffery, Berlin-New York 1994.

$I G C H=$ An Inventory of Greek Coin Hoards, ed. by M. Thompson, New York 1973.

Isocrates, vol. 2, ed. and transl. by G. Norlin, Cambridge, Mass.-London 1929.

Nepos, Cornelius, in: Lucius Annaeus Florus, Epitome of Roman History, ed. and transl. by E. S. Forster / Cornelius Nepos, ed. and transl. by J. C. Rolfe, London-Cambridge, Mass. 1929 (repr. 1947, 1960, 1966).

Plato, vol. 9: Timaeus, Critias, Cleitophon, Menexenus, Epistles, ed. and transl. by R. G. Bury, Cambridge, Mass.-London 1929 (repr. 1942, 1952, 1961, 1966, 1975).

Plutarch's Lives, vol. 2: Themistocles and Camillus. Aristides and Cato Major. Cimon and Lucullus, ed. and transl. by B. Perrin, Cambridge, Mass.-London 1914 (repr. 1928, 1948, 1959); vol. 3: Pericles and Fabius Maximus. Nicias and Crassus, ed. and transl. by B. Perrin, Cambridge, Mass.-London 1916 (repr. 1932, 1938, 1951, 1958).

Pseudo-Skylax's Periplous. The Circumnavigation of the Inhabited World. Text, Translation and Commentary, ed. and transl. by G. J. Shipley, Bristol 2011.

81 For the changes Cyprus underwent in the 4th century BC, see Körner 2016, 36-44; Körner 2017, 239-289. 
Suda On Line. Byzantine Lexicography, https://www.cs.uky.edu/ raphael/sol/sol-html/index.html (accessed: 2 February 2020).

Thucydides, vol. 1: History of the Peloponnesian War Books I and II, ed. and transl. by C. F. Smith, Cambridge, Mass.-London 1919 (rev. and repr. 1928, repr. 1935, 1951, 1956, 1962).

Thukydides, Der Peloponnesische Krieg, ed. and transl. by G. P. Landmann, Düsseldorf ${ }^{3} 2010$.

Xenophon, Cyropaedia, ed. and transl. by W. Miller, vol. 2: Books V-VIII, Cambridge, Mass.-London 1914 (repr. 1932, 1943, 1953, 1961, 1968, 1979).

\section{Secondary Literature}

Anselm, S. (2004), Struktur und Transparenz. Eine literaturwissenschaftliche Analyse der Feldherrnviten des Cornelius Nepos, (Altertumswissenschaftliches Kolloquium - 11), Stuttgart.

Badian, E. (1987), The Peace of Callias, JHS 107: 1-39.

Barns, J. (1953), Cimon and the First Athenian Expedition to Cyprus, Historia 2: 163-176.

Egetmeyer, M. (1993), Zur kyprischen Bronze von Idalion, Glotta 71: 39-59.

Egetmeyer, M. (2010), Le dialecte grec ancient de Chypre, vol. 1: Grammaire; vol. 2: Répertoire des inscriptions en syllabaire chypro-grec, Berlin-New York.

Georgiadou, A. (2010), La tablette d'Idalion réexaminée, Cahiers du Centre d'Études Chypriotes 40: 141-203.

Hornblower, S. (1994), Introduction, in: S. Hornblower (ed.), Greek Historiography, Oxford: 1-72.

Iacovou, M. (2002), From Ten to Naught: Formation, Consolidation and Abolition of Cyprus' Iron Age Polities, Cahiers du Centre d'Études Chypriotes 32: 73-87.

Iacovou, M. (2006), "Greeks," "Phoenicians" and "Eteocypriots": Ethnic Identities in the Cypriote Kingdoms, in: J. Chrysostomides, C. Dendrinos (eds.), "Sweet Land...": Lectures on the History and Culture of Cyprus, Camberley: 27-59.

Iacovou, M. (2013), Historically Elusive and Internally Fragile Island Polities: The Intricacies of Cyprus's Political Geography in the Iron Age, BASOR 370: 15-47.

Körner, C. (2016), The Cypriot Kings under Assyrian and Persian Rule (Eighth to Fourth Centuries BC): Centre and Periphery in a Relationship of Suzerainty, Electrum 23: 25-49.

Körner, C. (2017), Die zyprischen Königtümer im Schatten der Großreiche des Vorderen Orients. Studien zu den zyprischen Monarchien vom 8. bis zum 4. Jh. v. Chr., (Colloquia Antiqua-20), Leuven.

Körner, C. (2020), Die zyprischen Könige des 4. Jahrhunderts v. Chr. „Kleinkönige“ mit einem königlichen Selbstbewusstsein?, in: M. Grawehr, C. Leypold, M. Mohr, E. Thiermann (eds.), KlassikKunst der Könige / Kings and Greek Art in the 4th Century BC. Tagung an der Universität Zürich vom 18.-20. Januar 2018, (Zürcher Archäologische Forschung - 7), Rahden, Westfalen: 153-162.

Körner, C. (forthcoming), The Polity of Idalion: A Constitutional Government of King and Polis or a Monarchy with Institutions?, in: S. G. Schmidt, W. M. Kennedy (eds.), The Topography of Ancient Idalion and Its Territory, (Studia Cyprologica, vol. 2), Berlin.

Lendle, O. (1992), Einführung in die griechische Geschichtsschreibung. Von Hekataios bis Zosimos, (Die Altertumswissenschaft), Darmstadt.

Luce, T. J. (1997), The Greek Historians, London-New York.

Mehl, A. (2013), Zyperns Rolle im Überseehandel mit dem Ägäisraum (5.-4. Jh. v. Chr.), in: A. Slawisch (ed.), Handels- und Finanzgebaren in der Ägäis im 5. Jh. v. Chr., (BYZAS, vol. 18), Istanbul: 135153.

Meiggs, R. (1972), The Athenian Empire, Oxford.

Meister, K. (1982), Die Ungeschichtlichkeit des Kalliasfriedens und deren historische Folgen, (Palingenesia-18), Wiesbaden.

Papantoniou, G. (2012), Religion and Social Transformations in Cyprus: From the Cypriot Basileis to the Hellenistic Strategos (Mnemosyne Supplements. History and Archaeology of Classical Antiquity - 347), Leiden-Boston.

Parker, S. T. (1976), The Objectives and Strategy of Cimon's Expedition to Cyprus, AJPh 97: 30-38. 
Peltenburg, E., Iacovou, M. (2012), Crete and Cyprus: Contrasting Political Configurations, in: G. Cadogan, M. Iacovou, K. Kopaka, J. Whitley (eds.), Parallel Lives: Ancient Island Societies in Crete and Cyprus, (British School at Athens Studies - 20), London: 345-363.

Raptou, E. (1999), Athènes et Chypre à l'époque perse (VI - IV s. av. J.-C.). Histoire et données archéologiques, (Collection de la Maison de l'Orient méditerranéen, Série archéologique - 28), Lyon.

Raptou, E. (2016), The Relations between Athens and Cyprus during the Classical Period, transl. by G. Bourogiannis, in: Kyprios Character: History, Archaeology \& Numismatics of Ancient Cyprus, kyprioscharacter.eie.gr/en/t/Ak (accessed: 2 February 2020).

Stylianou, P. J. (1992), The Age of the Kingdoms: A Political History of Cyprus in the Archaic and Classical Periods, MEAETAI KAI YПOMNHMATA of the Archbishop Makarios III Foundation 2: 375-530.

Stylianou, P. J. (1998), A Historical Commentary on Diodorus Siculus Book 15, (Oxford Classical Monographs), Oxford.

Tuplin, C. (1996), Achaemenid Studies, (Historia Einzelschriften - 99), Stuttgart.

Wiesehöfer, J. (2000), Großkönige und Stadtfürsten - Eteokyprer, Griechen und Phoiniker. Geschichte Zyperns in klassischer Zeit, in: S. Rogge (ed.), Zypern. Insel im Brennpunkt der Kulturen, (Schriften des Instituts für Interdisziplinäre Zypern-Studien - 1), Münster-New York-München-Berlin: $143-158$.

Zenzen, N., Mehl, A., van Ess, M. (2013), Wirtschaft im Spannungsfeld zwischen Ost und West: Der Handel im östlichen Mittelmeergebiet achaimenidischer Zeit, in: N. Zenzen, T. Hölscher, K. Trampedach (eds.), Aneignung und Abgrenzung. Wechselnde Perspektiven auf die Antithese von 'Ost' und 'West' in der griechischen Antike, (Oikumene. Studien zur Weltgeschichte - 10), Heidelberg: 292-366.

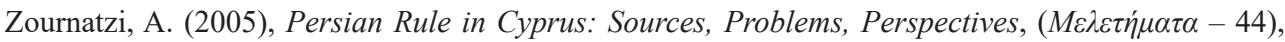
Athens. 